\title{
SOME REFLECTIONS ON THE ORIGIN OF QOM
}

- myth and history-

\section{Takamitsu SHIMAmoTo*}

\begin{abstract}
A sacred place is what it is because of the permanent nature of the hierophany that first consecrated it....

There, in that place, the hierophany repeats itself. In this way the place becomes an inexhaustible source of power and sacredness and enables man, simply by entering it, to have a share in the power, to hold communion with the sacredness. This elementary notion of the place's becoming, by means of a hierophany, a permanent "centre" of the sacred, governs and explains a whole collection of systems often complex and detailed.(1)
\end{abstract}

The concept of "center" in any religion, whether that in world religion or tribal or personal one, is of great significance, for this "center" creates in the heart of each believer undescribable feelings, awe-inspired at one time and catharsisized at another, making his religious life truely meaningful. Thus, it is indispensable for religious man to feel that he is living at the "center". M. Eliade seems to insist this sort of "center" exists almost inumerably, that is, each religious man possibly has his own "center" wherever he subjectively recognizes hierophany, something sacred.(2) The structure of "center" for religious man may be like this, but how can we explain, objectively as well as subjectively, the process of both physical and spiritual formation of first-class religious "centers" in the world, such as Isejingu (伊 勢神宮), Jerusalem, Mecca, Mashhad, and Qom, etc. ? Here we encounter a historical problem along with a mythological one. Each "center" as we see it now has gone through its own evolutionary process before it has become an acknowledged "center", being restricted by its own historical conditions (time and space factors). Therefore, besides the knowledge of structure of "center" in theory, at the same time, it is indispensable for us to know

* Lecturer, Osaka University of Foreign Studies 


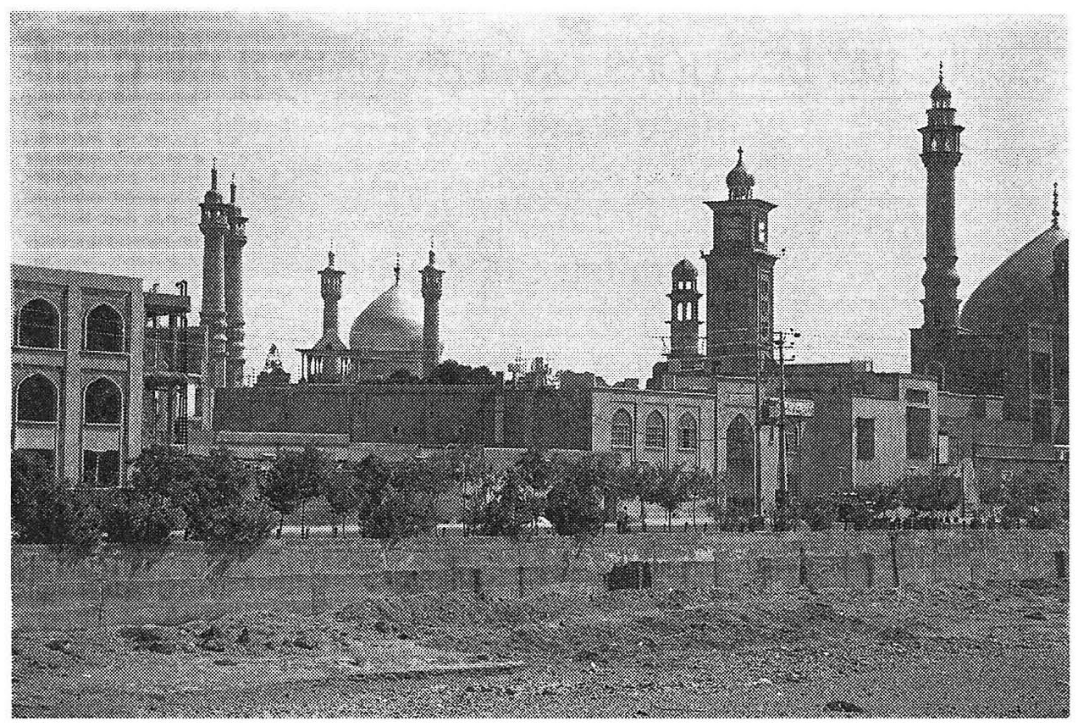

Present Shrine of Fatemeh (1986)

the process of formation of "center", in other words, to search for the historical origin of "center". In this paper, the case of Qom will be discussed as a concrete example, so that we will clarify the point at issue.

The city of Qom, which is located some $150 \mathrm{~km}$ south of Tehran, is now one of the most important politico-religious centers not only in Iran, but in the whole Shi'te world. Along with yet another celebrated religious center within the Iranian border, Mashhad, eternal resting place of the eighth Imām, 'Ali al-Rezāa, Qom has attracted a number of believers to the holy shrine of Fāṭemeh, Haẓrat-e Ma'șūmeh, Imām Rezā's sister and daughter of the seventh Imām, Mūsā al-Kāzẹem. Present author will make an access to the origin of the city from two different angles, namely, by means of both historical and mythological (Imāmi hadith) documents although these two sources are not always contradictory, but more often than not supplementary. By so doing, will the origin of Qom be reflected and some allusions to its present significance made. The basic sources are listed below and will be referred to in abbreviated form as follows;

(1) 'Alì Asghar Faqihi, Tārīkh-e Madhhabi, Târīkh-e Jāme’-ye Qom, n. d., T. $M$.

(2) Fayẓ, Ketāb-e Ganjineh-ye Āthār-e Qom, Qom va Rowẓeh-ye Fātemieh, 1349/q. Qom., G. A. Q. 
(3) Hasan b. Moḥammad b. Hasan-e Qomi, tr. by Ḥasan b. 'Ali b. Hasan 'Abd al-Lāh-e Qomi, Ketāb-e Tārïkh-e Qom, 1361/q, Tehran., K. T. Q.

(4) Mehdi Sahfi, Zendegāni-ye Haẓrat-e Ma'șūmeh va Tārïkh-e Qom, 1378/ q., Qom. Z. H.

(5) Moḥammad Ḥosein Nāser al-Sharì' eh, Tārikh•e Qom, n. d., Qom., T. Q.

(6) Moḥammad Sharif-e Razī, Ganjīneh-ye Däneshmandān, 1352/sh., Tehran., G. $D$.

(7) Safi al-Din, Moḥammad b. Moḥammad Hāshem-e Hoseini-ye Qomī, Kholāṣat al-Boldān, n. d., Qom, Kh. B.

\section{Origin of the name of Qom}

Several theories have been presented as to the origin of the naming Qom a few of which seem to be plausible although it is not in the least easy, rather almost impossible to decide which one is the true reason for its present appellation.(3) According to one explanation, after the Arab tribe, Asharites came to the present Qom area, they built seven villages, namely Mamjān, Qazdān, Malūn, Jamr, Sakn, Jolanbdān and Komìdān. As time went on, these seven villages became closer to one another because of population increase and expansion of each village. Komidān, which is said to have been the largest of all, came to represent them. Then the word Komidān became shortened into Kum (Kom), then Arabized into Qum (Qom).

A second theory goes as follows; there is said to have been a water place around the present day Qom area, where water plants and birds were abundant. This place was called Kabūd Dasht. In Arabic any place where water gathers is called qamqamah in singular (in Persian äftäbeh, water basin) and qamāqem in plural, which was shortened into Qum. A third reason, which according to the author of $K$. T. Q., seems to be the most plausible, is this; as is mentioned above, since the area under discussion was suitable for pasture, many shephards came to the area for feeding their cattle. While staying there, they set up the tents called kumeh, which again became shortened with the passage of time into Kum and then Arabized into Qum (Qom).

At present, it is almost impossible to determine which is the true reason for naming the city.(4) Depending on where to put emphasis, how- 
ever, two different kinds of interpretation might be possible as to the origin of the name. One is the position which emphasizes a continuity between the pre-Islamic period and that after the coming of Islam. The other is a view point according to which the city had become important only after the advent of Islam and tries to minimize "Jahiliya" tradition in the formation of the city. Once in a while we come across this contrast, such as the relationship between Islam and Zoroastrianism when we discuss historical origin of Qom in the following section. Nevertheless, there is no denying the fact that the importance of Qom had been finalized after the advent of Islam though there must have been a certain kind of continuity between pre- and post-Islamic era.(5) Therefore, stress will be put on the Islamic era in the following discussion.

\section{Historical Origin of Qom}

At the end of the Umayyad dynasty and right after the establishment of the 'Abbasid dynasty, the Shi'ite believers had been forced to live under harsh condition. This situation was to lead to their migration from Iraq to various places in the Muslim world, where they could expect to lead more or less peaceful lives. Some districts in Iran, such as Sāveh, Āveh and Tabarestān, provided those havens for the 'Alids.

It is said that in the last quarter of the 7th century the first Arab Moslems came to Qom area on their way to Esfahān when they continued their expedition journey to conquer the latter area.(6) On this occasion, however, they did not pass through Qom because the city, unlike today, was not located on the main roads at the time and the area was of minor importance for the Arabs. Therefore, it is generally admitted that the first settlement by Arab Moslems in the city took place in 701A. D., when Ahvvas, leader of fleeing Asharite tribe, came to the city, who were said to to be Shi'a. It was during the reign of Caliph 'Abd al-Malek (685-705) that this took place. (7) Since Hajjāj b. Yūsef, governor of Iraq, took harsh measure toward Shi'ite believers, this compelled the aforementioned group to escape from Küfeh. It is also said that their migration (expulsion) from Küfeh had something to do with the rebellion of Zayd b. 'Ali B. al-Hosein b. 'Ali b. Abi Tāaleb. Indeed a series of events, which took place in this crucial period for later Shi'ite development, such as Kerbelā tragedy in 680, the 
uprising of Tawwabūn right after this, the rebellion of Mukhtār in 685, caused Iraq an extremely difficult place for the Shi'a to live in. As is indicated above, the situation had been made even worse by the appointment of Hajjāj by 'Abd al-Malek in 695 . The period coincided with the one during which the Umayyads made a serious attempt to solidify its foundation by introducing centralized apparatus of goverment.

The story of the coming of the 'Arabs is given in $K . T . Q$. in detail. (8) As for the coming of two brothers, Aḥvas and 'Abd al-Lāh, we have a few different versions at hand. One of them says: Ahvas sided with Zayd b. 'Ali b. al-Ḥosein b. 'Alì b. Abi Țāleb when he rebelled in Kūfeh. He was appointed by Zayd as army commander (amir-e lashkar). However, soon Zayd was killed and Ahvas was also taken captive and put into prison because of his connection with the rebel. Although he had been in prison for several years, he was finally set free perhaps as a result of his brother's petition for his release. It was not long before Hajjāj repented he had set Ahvas free so he tried to arrest him once again. The situation being like this, 'Abd al-Lāh, who was constantly in touch with his brother, Aḥvas, thought Küfeh was no longer a good place for them to live in and advised his brother to leave it to find some other better place. In this way, they were determined to leave Küfeh. Ahvvas, who was in more dangerous position, left the city prior to his brother and 'Abd al-Lāh followed him after he sold everything of his own possession. In 82A. H. (701), Ahvas came to the vicinity of present day Qom by way of Bașreh. On his arriving, the natives of the area, since they had been suffering from annual intrusions by the Dailamites, asked him to settle in the area on condition that he would protect them from the Dailamites' attacks. Ahvas accepted this and made up his mind to settle there. His brother 'Abd al-Läh came to the same district soon after to know that his brother had decided to settle in the place. Unhappy as he was at first, his brother's persuasion finally melted the heart of 'Abd al-Lāh and made the latter accept the decision. Five years later, the new comers, who probably had been living in tents till then, were given a village named Mamjān for their permanent settlement. From this time on, the 'Arabs became prosperous, which later caused envy in the hearts of the native dwellers, ending up with the disastrous massacre of the latter.

At any event, an extremely significant event occurred after the 'Arabs Vol. XXVII 1991 
settlement in the area. Now that 'Abd al-Lāh, who had been reluctant to settle in the area, decided to live there permanently, he wanted to build a mosque in order to pray in. So Ahvas destroyed a Zoroastrian fire temple and a mosque was built on the very spot. As far as the knowledge of present author goes, this is the very first mosque built within the city though it is said there was yet another building for prayer at Jomkerān, a village a few kilo-meters south of the city.(9) This event could be regarded symbolically as marking the starting point of Islamization of the area.

As is mentioned above, the 'Arabs settled in the area had become prosperous and the city itself known as a shelter for the Shi'ite refugees at least by the time Fātemeh came to the city to breathe her last breath in the year 816. Now we shall discuss the event of how Fătemeh, Hazrat-e Ma'șumeh came to Qom by starting with the related story of his brother's coming to Iran.

Having taken the place of his father's, Mūsā al- Kāzem, 'Ali al-Rezāa became Imām in 799. When he became Imām, the 'Abbasid dynasty was the ruler of the vast Islamic world including present Iran. In the early 9th century, this vast empire was ruled by the two sons of Hārūn al-Rashid (786-809), Amin (809-813), and Ma'mūn (813-833). The eastern part of the empire was under the control of the latter when he invited the 8th Imām to Merv, located in north-eastern Iran so that he might allegedly appoint the Imām as his own successor. Whatever the true motivation of this invitation might have been on the side of Ma'mūn, 'Ali al-Rezā accepted it and left Madina for Khorāsān in 815 , being welcomed there. Although the Imām is said to have been actually appointed as Ma'mūn's successor, change of political situation in Baghdad forced Ma'mūn to return to the capital of the empire. 'Ali al-Rezā himself followed him and suddenly died at Tūs on his way back to the capital. The Shi'a believe that their Imām was killed by Ma'mūn. (10) No matter where the truth might have lain, his burial place, present Mashhad, was to become the largest and most celebrated imāmzädeh within the Iranian territory.

Within less than a year or so, his sister Fātemeh made up her mind to go to Khorāsān to meet her brother in 816.(11) At present we have no means to know which course she took for her last journey though there must have been several courses at the time.(12) Our source only says that when she came to Sãvah, located some $60 \mathrm{~km}$ north-west of Qom, she was 100 


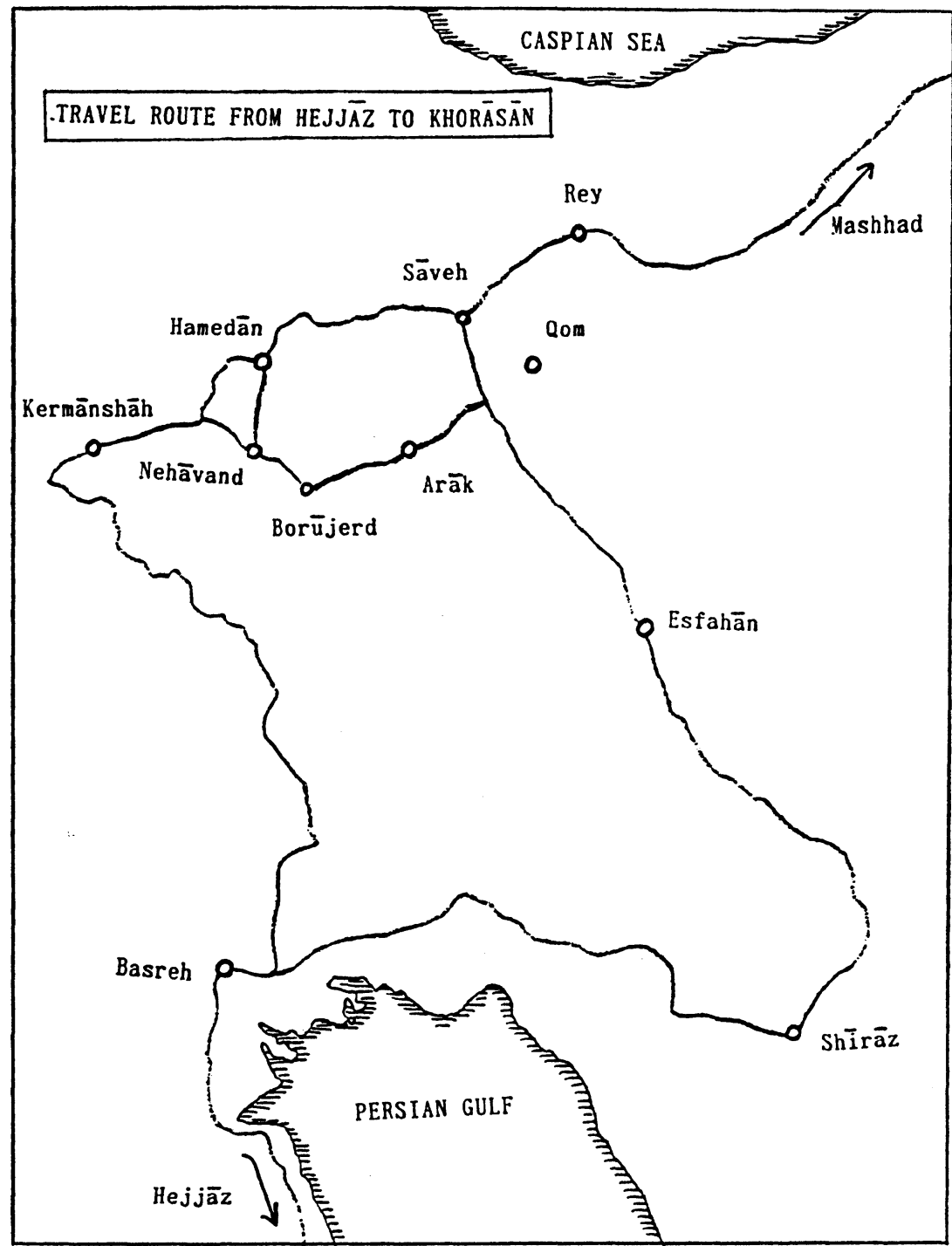

taken ill, transported to Qom and died there. According to K. T. Q. :

....the notables in Qom report the following story; 200A. H., after Imām Rezā left Madinah for Merv so that he might get bay'a from the people (of Țūs), Fāṭemeh, his sister and daughter of Imām Musā, also left (Madinah) in 201A. H., following her brother. When she arrived at Sāveh, however, she was taken ill. Asking her fcllowers how far it was 
from there to Qom, she got the answer, "It is 10 farsangs (approximately $60 \mathrm{~km})$." Then she ordered her attendents to take her to that city. Accordingly, they took her to the city and she stayed at the house of Mūsā b. Khazraj b. Sa'd Asha'ri. (Nevertheless, according to the author of $K . T . Q$.) the truth was this: when the news (of Fātemeh's arrival at Sãveh) reached the Asharites in Qom, they unanimously agreed that they should invite Hazrat-e Ma'șūmeh to the city and welcome her. From among them, a man named Mūsā b. Khazraj left the city alone at night and brought her to his own residence. She stayed alive there for only seventeen days. After she passed away, they washed her body and put it in a coffin. After the prayer done, Mūsā b. Khazraj buried her corpse in the land called Bābelān, which was his own property. At present, there is the holy rowzeh at the same spot. They made a cover made out of reed, shadowing her tomb. (13)

As far as present author's knowledge goes, this is the oldest and most lengthy description concerning Fātemeh's coming down to Qom.

Although little information is available on the situation of Qom during the period between the settlement of the Asharite 'Arabs and Fātemeh's arrival, we can assume that there must have been not a few sympathizers of Shi'ite movement in Qom for her statement cited above indicates she knew to some extent sizable number of supporters of 'Alides were residing in the city. In addition, as afore-mentioned historical process of the first 'Arabs' coming to Qom indicates, most of them may have been Shi'a or those who had Shi'ite tendency.

At any event, the fact that the Imām's daughter was buried in Qom gave a great impetus to later development of the city, resulting in the inflow of many other sayyids' visiting the city and many of them were allegedly buried there. (14) It is said in a rather exaggerated manner that there are 444 imāmzādehs in the city. (15) Though Bābelān, Fāțemeh's eternal resting place, was originally located at the southern part to the city away from Komidān and Mamjān, which were the center of the city at the time, with the passage of time her tomb helped shift the gravitation of importance from the north to the south. As a result, her shrine has occupied the very center of Qom as we see it now.(16) In this manner, the city of Qom was to develop as one of the most celebrated and important centers in the Shi'ite world. 


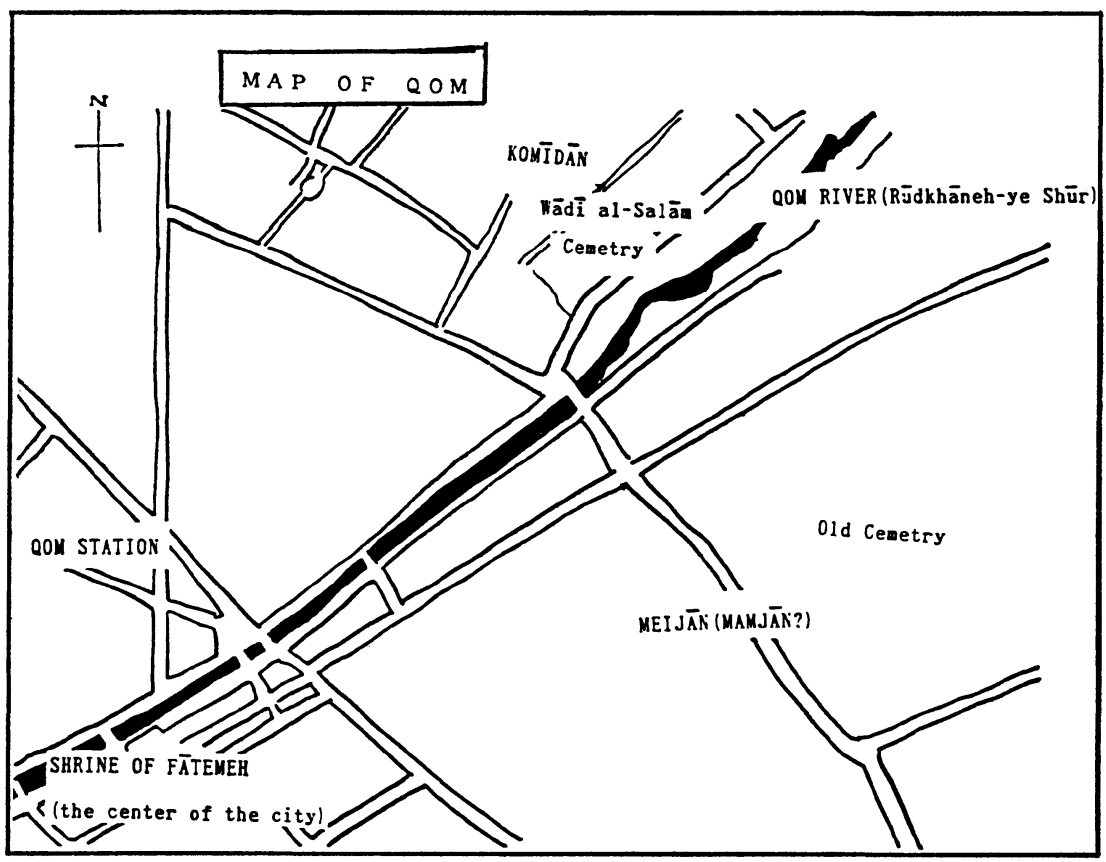

\section{Origin of Qom and its virtues found in hadith literature}

Forty traditions are transmitted to us concerning the origin and virtues of Qom. Already in K. T. Q., we can find basic motifs of them, which describe the hows and whys of Qom's becoming the most virtuous and celebrated place in the Shi'ite world, i. e., "center". Through the examination of these hadith literature, it is by no means difficult to observe the reflection of the time when those traditions were written and obvious rationalization of the position of Qom as a center of growing significance. In particular, they reflect the hardest period for the Shi'a, namely from the end of the 7 th century up to the beginning of the 10th century. Therefore it can not be coincidental that the Shi'ite doctrine of Mahdi (messianism) was formulated during this crucial period.(17) In this respect, these traditions may have been historical products, so that the position of Qom and its role to be played might be justified or rationalized, but once they were accepted as truth among beievers, they could have a certain kind of universal con- 
Table: Classification of forty hadiths according to the themes, Kh. B. pp. $50-82$.

\begin{tabular}{|l|l|}
\hline $\begin{array}{l}\text { Qom as an asylum from } \\
\text { oppressors }\end{array}$ & $\begin{array}{l}\text { hadith number } \\
34\end{array}$ \\
\hline $\begin{array}{l}\text { Qom as a center of religious } \\
\text { science }\end{array}$ & 19,24 \\
\hline $\begin{array}{l}\text { Qom as the most blessed city } \\
\text { by the Divine }\end{array}$ & $\begin{array}{l}1,2,8,12,15,16,27,33,14,18,21,22,23, \\
25,26,30,31,35,36,39\end{array}$ \\
\hline $\begin{array}{l}\text { Qom as a pilgrimage place } \\
\text { (and its healing power }\end{array}$ & $4,6,9,10,20,37,38,40$ \\
\hline $\begin{array}{l}\text { Though some of these are overlapped as to their contents, } \\
\text { classification has been made according to the main theme. No. 17, } \\
29 \text { and } 32 \text { seem not to belong to any of these classification. }\end{array}$
\end{tabular}

notation for each believer, who interpretes them and applies his interpretation to comprehend meaning of life and world in which he lives.

$K h$. B. records those forty traditions concerning Qom, which could be classified into four categories in accordance with their contents, as follows;(18)

1) Qom as an asylum from oppressors,

2) Qom as a center for religious science,

3) Qom as the most blessed city by Godhead,

4) and Qom as a pilgrimage place (especially with connection with Fāṭemeh Haẓrat-e Ma'șūmeh)

Now we shall introduce some of the representative hadiths following each classification above.

As for the hadiths referring to Qom as an asylum for believers, the tradition no. 3 says;

Mohammad b. Ya'qūb Kolaini transmits this tradition based on the transmission from Ya'qūb b. Yazid, to whom it is transmitted from Soleimān b. Sāleh, who (i. e. Soleimān b. Sāleh) one day was in the presence of Imām Abi 'Abd al-Lāh Ja'far b. Moḥammad al-Șādeq (peace be upon him). The master made a statement about the upheavals of 
the 'Abbasids and what has happeded to the sayyids and Shi'a. Then we said to the master, "Oh, master, may we be your sacrifice! Since the situation is like this, where is the place for shelter and asylum for the Shi'a ?" Then Imām Ja'far Șādeq answered, “Wherever you may go, there will be rebellions and disturbances. So it is incumvent upon you to take an asylum to the city of Qom and its vicinity because God, Most High has expelled and will expell any calamities from Qom and its districts."(19)

There are some other hadiths of the same contents but suffice it here to quote only this one as an example.

As for the hadith describing the city as a center of religious science, the following must be the most famous and important. Tradition no. 24 goes as follows;

This hadith also traces its source back to Imām Ja'far al-Ṣādeq. One day the Imām thought of Kūfeh and said, "It will not be long before Küfeh is emptied of Shi'a and believers. And knowledge, wisdom and its people will dispppear as if a snake hid itself and disappeared in a hole. Afterwards the knowledge and wisdom will appear in the city, which is called Qom. Hidden knowledge and treasured secret will be made apparent in that city and the city will become a soure of meritorious and wise people and (the wisdom) will be propagated until no one on the earth remains weak in his faith. Such being the case, even the women in harem will acquire the knowledge about Imamat and Veläyat and this means the occultation and dispappearance of the Last Imām (Qā'em-e $\bar{A}$ l-Mohammad) draws near. Then God, Most High, shall make Qom and its people Hojjat (sign) for the created. If this is not the case, everything on the earth will be ruined....(20)

Despite the fact that there is a difference of opinion concerning the meaning of this tradition, (21) we take this as indicating the total decline of fame and influence of Kūfeh as a result of construction of Baghdād as a new capital on the one hand and Qom's growing reputation as a center of religious science among the Shi'ite believers. ${ }^{(22)}$

A third category of traditions depicts the city as the blessed one by the Divine and the virtual promised land for the oppressed Shi'a. According to the tradition no. 8 , which is also traced back to Imām Ja'far al-Ṣādeq, who says; 
"Know and be informed that God, Most High, has His own harām, that is Mekkeh, and there is the haram for the Prophet, that is Madinah, and also there is the haräm for Amir al-Mūmenin ('Alì b. Abi Tāaleb), that is Küfeh. Then my harām and the harām for my children after me is the district of Qom and Qom is a small Küfeh. Then, know that there are eight doors to heaven, three of which are open at Qom. (23) Truely a woman among my children named Fāțemeh binnat Mūsā will die in that city and all of our Shi'a will enter the Heaven through her intercession. (24)

This hadith includes the same motif that belongs to a fourth category, namely the one presenting the city as a holy and meritorious pilgrimage place, to which we shall refer below.

The group of traditions supporting the notion that Qom is the very location blessed by Godhead may include yet another hadith emphasizing that the city is the promised place and its people are, so to speak, the chosen one for the coming messiah, Qā'em Maqām (Moḥammad al-Montazer). For instance, hadith no, 23 (This hadith also has as its source Ja'far al-Ṣādeq) reads;

For God, Most High, no longer will there remain the hojjat (divine proof) for the sake of any cities and their people but Qom and its people. When there is no hojjat, the skies and grounds will not stay firm and within a twinkling of an eye the creatures will not raise an argument (about the hojjah). (But) all the hours and minutes, Qom and its people will be (free) from all this. The time will soon come when the hojjat of God will be shown to Qom and its people prior to all the creatures. This will be the time of Occultation of Qā'em-e Āl-e Mohammad and Qom and its people will be the deputy of the hojjat until His (peace be upon Him) appearance. If in this way, God Most High, does not make Qom and its people deputy of Qā'em-e Āl-e Moḥammad from the time of Occultation to His appearance, the world should be fallen down and its people overthrown!(25)

This hadith continues, describing that the city will be protected from any sort of tyranny and oppression, which is an obvious reflection of the harsh period for the Shi'a as we repeated the point earlier.

The last category of traditions, as we have already shown a part of it in the previous hadith, has something to do with Fātemeh Hazrat-e 
Ma'șūmeh and other imāmzādehs. The characteristic of this group of hadiths is that they promise the salvation of believers and healings of physical and mental ailment through miraculous power (barakat) of the holy Imāmi family members (imamzādehs). Besides the tradition 8 cited above, yet another specimen reads as follows;

This is a tradition that is transmitted through the genuine chain of transmission from Ja'far b. Moḥammad al-Ṣādeq (peace be upon him). It was on the occasion where a group of the people from the district of Rey came to Imām's presence. The Imām asked, "What group do you belong to?" They answered, "We are people from Rey." Then the Imām said, "Welcome, brothers from Qom!" The group said, "Oh, master! We are the people from Rey." Again the Imām replied, "Welcome, brothers from Qom!" In this way the same words were exchanged among them three times.

Then the Imām said, "There is the haräm for God, Most High, that is Mekkeh. There is the haram for the Prophet, that is Madinah. There is the harām for Amir (al-Mūmenin, i. e. 'Ali), that is Küfeh. There is the haram for us, that is Qom. Soon one of my children, whose name is Fātemeh, will be buried in Qom. Everone that makes his pilgrimage to her shrine and acknowledges this honor, will be sure to enter the paradise.

It is also narrated that when Imām Șādeq (peace be upon him) said this, Imam Mūsā (peace be upon him) had not been born and her mother was not even pregnant yet. We shall discuss how Hazrat-e Fāṭemeh binnat-e Mūsā came to Dār al-Mūmenin (i. e. Qom), passed away and was buried, if God wills, in the following chapter.(26)

Although the limit of space prevents us from scrutinizing all the forty traditions cited in $K h$. B., we could get acquainted with their general characteristics. Against this background, our next step is to examine the co-relationship between these traditions and historicity and then their effects upon the interpretation made by believers of the position of Qom as we see it at present.

\section{Origin of the city of Qom interpreted}

In the previous sections we have examined some traditions concerning the Vol. XXVII 1991 
origin of Qom. As is indicated earlier, in most of these traditions we could observe, more or less, reflection of the time in which the Shi'a suffered from fierce persecution inflicted by the Umayyads and 'Abbasids, ca. from the end of the 7 th century to the beginning of the 10th century. So we could look upon these traditions in one sense or another as actual historical documents, which were written during the time involved or may have been written later than that. Indeed there must have been not a few traditions now completely fallen into oblivion and never caught our attention. This being the case, however, it is important to note here that the traditions, only a few of which we have discussed above, have survived for many centuries and remain still alive, so that they have come to have universal meanings for believers and be regarded as solid truth on the ground that they all trace their origin back to the revered Imams. Here historicity is, so to speak, diluted and historical incidents have been interpreted into kinds of myths. These traditions have functioned so as to justify the celebrated and superior position of Qom though in the beginning they may have been written merely in order to record the harsh realities and hand them to the later generation as a proof of their faith. Historicity has been overcome by religious reality. Thus, the traditions, which were allegedly narrated by the holy Imāms, have been accepted as something true and genuine, and in the end established as a solid proof to demonstrate the fact that Qom is nothing but the "center" for the shi'a and of the Shi'ite world.

The traditions thus accepted increased in number as time progressed. Though we count some twenty traditions in $K . T$. Q., written at the end of the 10 th century, the number was inflated up to forty or maybe more in the Safavid work $K h$. B., written in the middle of the 17 th century. By then the position of Qom as "center" is said to have been solidified as a result of the orthorization by the dynasty of Twelver Imāmi Shi'ism as state religion.

At any event, this metamorphosis of historicity into myth or vice versa has made the city what it is today. We can no longer distinguish the one from the other once their mixture has been made so complete and accepted among the believers as something real. Based on this argument, next we shall summarize some characteristic features of Qom that have attracted many a Shi'ite believer to it for centuries and might allow it to be called "center". In this respect we might count three attributes of the city, namely;

(1) Qom as the source of miraculous power (barakat) — healings and worldly 
benefits as well as spiritual ones,

(2) Qom as the center of religious science from ancient past,

(3) Qom as the promised land for every believer's salvation.

Even though the strict Islamic doctrine prohibits every believer from worshiping Gods but al-Lāh, saint worship has developed hand in hand with the official creed. This is particularly the case with Shi'ism in Iran. Goldziher says;

The Persians especially have shown in their popular beliefs, as well as in dogmatic doctrines concerning imams, in the elaboration of which the Persian has (sic), as is well known, had the greatest clear element, that they have advanced far along the road to deification of holy men, and they have expressed this tdndency manifoldly in their legends about saints.... (27)

Miraculous power, emanating from the tombs of Fātemeh and other imāmzādehs, are sanctioned only because they are the descendents of the Prophet, his daughter Fātemeh Zahrā, her husband 'Ali, and other eleven Imāms. This miraculous power cannot help but attract the believers, who are afflicted with destitution, ailment, etc., on the one hand, filled with joy and affection toward Imaams and their family members on the other. We have a number of such stories as to demonstrate Imāmi barakat, which in most cases are healings of long suffering diseases and physical handicaps. (28) By the way, such places full of barakat are called BAST in

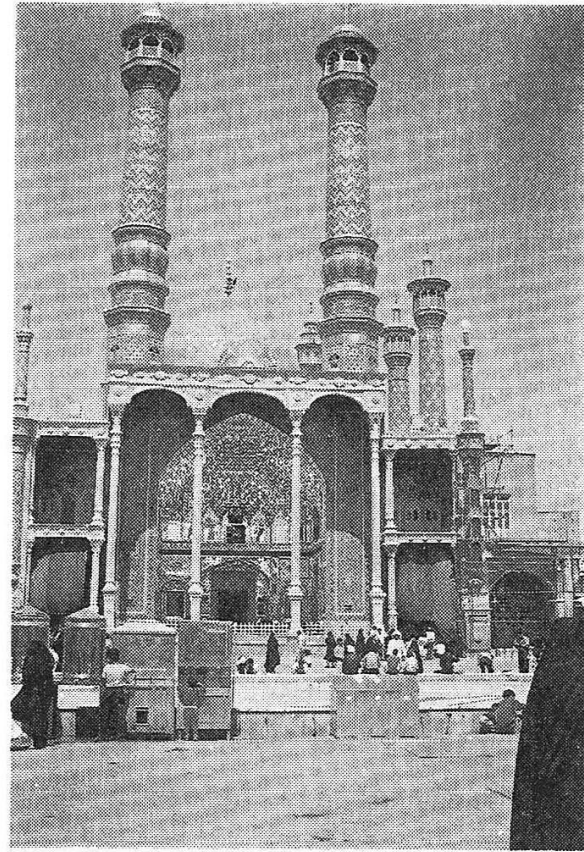

Shrine of Fātemeh and pilgrims (1986)

Persian (sanctuary, asile), ${ }^{(29)}$ where even a criminal is safe from punishment untill some kind of agreement is reached between him and his pursuer. Qom had been well-known as BAST since there are many holy shrines and tombs of saints there, among which the shrine of Fātemeh is of the Vol. XXVII 1991 
highest rank, of course.

Yet another characteristic of Qom is its function as a center of Shi'ite religious sciences, as is symbolically illustrated in the story of declining influence of Küfeh like a snake hiding in a hole. Such was the prosperity of the city as a religious center from the 9 th century up to the eleventh century that modern books on the city never fail to refer to this period and those who were distinguished for their scholarly activities, for instance, Shaykh al-Ṣodūq. As for the modern age, in particular since the 1920's on, when Ayat al-Lāh Hā'eri came to the city and settled permanently, so that he re-established Howzeh-ye 'Ilmieh, Qom has been without exaggeration a champion of Shi'ite religious sciences. ${ }^{(30)}$ It is interesting to note that alRazi, when he explains the situation of re-construction of Howzeh, based on several hadiths, refers to the predestined role the city was to play in the Shi'ite world.(31) The fame of Qom after 1950's and 1960's was tremendous under the leadership of Borūjerdi(32) and particularly after the revolution of 1979, Qom has been acknowledged as both religious and political center.

A final conspicuous characteristic of Qom is that it has been depicted as the place of Divine proof (hojjat) until the coming of the last Imām (Mohammad al-Montazer). It may be true that the doctrine of occultation, though it also meant apoliticization of Shi'a, developed to a remarkable extent during the 9 th and 10th century chiefly because of harsh persecution by the 'Abbasids. But, with the passage of time, this doctrine came to provide the ultimate foundation of raison d'être of Imami Shi'ism because the coming of the Mahdi is no doubt the promise to finalize every believer's expectation and hope of his salvation. Therefore, the fact that Qom has been given the position of hojjat indicates what a crucially important role the city was expected to play by the believers.

In this paper we have discussed the origin of Qom from four different aspects, that is, (1) the origin of its name, (2) its historical origin, focusing on that after Islamic era, (3) its origin found in hadith literature and (4) its origin interpreted by believers. In this attempt to understand the origin of Qom, we can see that there are two factors that are crucial in the formation of the city, namely historical background and mythical one. It may be possible to formulate a history of Qom based on historical documents alone, but we can not cast aside mythical element, either, or vice versa. This is simply because 
the true meaning of history of Qom could be comprehended not only by observing objective historical conditions, but also taking into consideration highly subjective faith of believers. These two elements have been intertwined so closely that we cannot separate the one from the other. As we pointed out at the very beginning of this paper, the balance between theory and historicity is of the utmost importance for more accurate understanding of the relationship between religion and history.

The city of Qom is one of the most important religious and political centers for Iranians at present and throughout the history of the country has been respected and visited by inumerable believers so that they could share miraculous power (barakat) of descendents of the Imāms. As long as the believers need to have mythical experience as an indispensable part of their religious life and to feel real, Qom is to play the same role of "center" as hitherto it has.

\section{Notes}

(1) M. Eliade, Patterns in Comparative Religion, tr. by Rosemary Sheed,, New York, 1974 , p. 368.

(2) As for the ideas of religious man and his sacred experience, see also Eliade, Images and Symbols; Studies in Religious Symbolism, tr. by Philip Mairet, Kansas City, 1961, and The Myth of Eternal Return or, Cosmos and History, tr. by Willard R. Trask, Princeton, 1974, etc.

(3) Almost every book on Qom deals with its origin of name based on the description of K. T. Q., pp. 20-25. Cf. Moḥammād Taqi Arbāb, Tārīkh.e Dār al-Imān-e Qom, pp. 10-11, and as to the etymological explanation, see $G . A . Q$. vol 1, pp. 77-88, where Fayz examines in detail five of the theories as to how the city came to be called Qom.

(4) There are several other interesting hadiths, which seem to be obvious rationalization of the position of Qom by relating it with Prophet Mohammad as is shown in the hadith, which depicts Mohammad sanctions the city on the occasion of his nocturnal ascension (Mirä'j).

(5) As for the continuity or discontinuity between pre- and post-Islamic era some authors imply or explicitly emphasize the continuity, for example, see $T$. $M$., pp. 49-62, where Faghihi tries to prove Qom's antiquity and its importance before the advent of Islam by being based on several documents esp., pp. 54-58. It is also pointed out that the origin of Qom has something to do with the Zoroastrain water godess, Anāhita, which at once reminds us of Fātemeh. There are several important places in the city which have some connection with water. See for instance T.Q., pp. 54,56. And also, as for the healing power of water, Kh. B., p. 62 .

(6) As for the general historical circumstance between the end of the 7 th century and the beginning of the 10th century, present author referred to the following sources, Dixon, 'Abd al-Ameer 'The Umayyad Caliphate, 65-86/684/705, London, 1971, Donaldson, D. M., The Shi'ite Religion, London, 1933, Momen, Moojan, An 
Introduction to Shi'i Islam; the History and Doctrines of Twelver Shi'ism, London, 1985, Shaban, M. A., Islamic History, a New Interpretation, 2vols., London, 1980, Shaykh al-Mufid, Kitäb al-Irshäd; The Book of Guidance into the Lives of the Twelve Imams, tr., by T. K. Howard, London, 1981, Johei Shimada (沜田袈平) insuramu no kokka to shakai （イスラムの国家と社会） Tokyo, 1977, etc.

(7) In the times we are discussing, there were several routes to go from Hejjāz and Iraq to Khorāsān, such as Bașreh-Khozestān-Fārs-Esfahān-Saveh-Khorāsān, Kermānshāh-Nehāvand-Hamedān-Sāveh-Khorāsān, or Karj Abi Dalf (near present Arāk)-Sāveh-Rey-Khorāsān, etc., see T. M., p. 85.

(8) K. T. Q., pp. 240-265, Cf. G. D., vol. 1, pp. 136-158.

(9) The author of $T$. $M$. referrs to the event that a person named Khttab b. Asadi erected a masjed at Jomkerān a few kilometers away from Qom, p. 117.

(10) E. g. Shaykh al-Mufid, op. cit., pp. 477-478, Sayyid Muhammad Husayn Ṭabātabā'i Shi'ite Islam (Shì'eh dar Isläm), tr., by Seyyed Hossein Nasr, London. 1975 , pp. 205.206, etc.

(11) This heart-breaking tragedy has made many a writer's imagination work freely so that he could create a number of literary works, especially eulogies which we can see on the walls of the shrine of Fătemeh at present. At the same time Fātemeh's trip to Khorāsān was made a theme of Ta'zieh play, Ta'zieh Haẓrat-e Ma'șūmeh. As for the latter, see my translation, sekai koshou bungei kenkyu (世界口承文芸研究), no. 9, 1987, Osaka.

(12) See Note (7).

(13) K. T. Q., p. 213

(14) Ibid., pp. 191-239. As for the sayyids living in the middle of the 19th century, see my "Society and Economy of Qom in the Latter Half of the 19th Century Iran", Orient, vol. 24, 1988, pp. 126-127.

(15) Moḥammad Taqi Beg Arbāb, op. cit., p. 39, etc.

(16) As for the location of the frist settlement of the 'Arabs and later development of the city, T. M., pp. 73-74, G. A. Q., p. 158, etc. It is said that the Asharites first settled down in the northern end of present Qom (left bank of the Qom river, Komidan and the right bank of the river, Meijān). Even after the center of the city had shifted to the southern part, the official buildings were still located in the northern part. See the attached map in the text.

(17) We have innumerable sources at hand as to the doctrine of ghaibat (occultation of the last Imām), for instance, Kolaini, Oșül-e Käfī (Ketāb al-Hojjah), Bāqer Majlisí, Bahār al-Anvār, esp. vol. 13 (Mahdī-ye Mau'ūd), Shaykh Ajjal b. Abi Zaynab, Ghaibat-e $N u^{\prime}$ manì, etc.

(18) Kh. B., pp. 50-83.

(19) Ibid., p. 55.

(20) Ibid., p. 76.

(21) As for the meaning of this hadith, Nāṣer Shari'eh, making use of variety of books concerning the issue, interpretes it as indicating that Küfeh was gradually declining while Qom was growing to be a source of knowledge and virtue. See T. Q., pp. 63-65. Cf., also, G. D., pp. 32-33 and Moomen, op. cit., p. 73.

(22) Besides many sayyids, a number of celebrated 'olamā and companions of the Imāms stayed, whether permanently or temporarily, in Qom, among others, Moḥammad b. Hạan Saffār, Abū 'Abd al-Lāh Moḥammad b. Khāled Barqi, Abū Jarir Zakariya b. Idris, 'Ali b. Bābūyeh, and the latter's son, Moḥammad, well-known 
as Shaykh al-Ṣodūq, see more in detail T. M., pp. 166-167, and T. Q., pp. 165-247, etc.

(23) According to a different source, only two doors to Heaven are open at Qom, one is within the city and the other at Jomkerān, where there is a famous mosque of Șāḥeb al-Zamān (the Last Imām).

(24) Kh. B., pp. 58-59.

(25) Ibid., pp. 69-70.

(26) Ibid., pp. 59-60.

(27) Goldziher, I., Muslim Studies (Muhammadnische Studien), tr. by S. M. Stern, New York, 1971, vol. 2, 294.

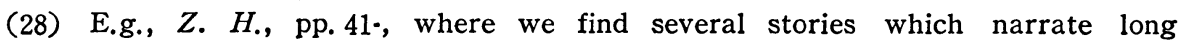
suffering illnesses have been healed by miraculous power of Fāțemeh. According to one story which the author of the book heard from Hojjat al-Islām Āqā-ye Ashikh Maḥmūd-e Arāki, when a certain crippled person who drew his lower part of his body by using his two arms, came from Dār al-Shafā' to Madreseh-ye Fayzieh and entered the harām (of Fāțemeh), Āqā-ye Ashikh saw him and came to know how bad his condition was. After this, on one of the nights of Ramazān, the same $\bar{A} q \bar{a}-y e$ Ashikh was on his way to Arāk. At the point six farsakh $(36 \mathrm{~km})$ to Arāk, he met that crippled man, who had been completely healed and was on his way to Kerbelā. Then, Aqā Āshikh asked him to get on his carriage and went rest of the way to Arāk with him.

(29) As for BAST, see my article, "Some Reflections on BAST; the Research on a Religious Practice in Modern Iran”, oriento, vol. 28, no. 2, 1985.

(30) As for the re-establishment and development of Howzeh-ye 'Ilmieh, see G. A. Q., pp. 314-324, G. D., Rāzi, Āthär al-Hojjah, pp. 13-76, etc.

(31) Ibid., pp. 17-21.

(32) As for Borūjerdi, see for instance, 'Abd al-Raḥim 'Aqīii Bakhshāhyesh, Foqahā-ye Nāmdār-e Shï'eh, n. d. Qom, pp. 445-452, etc. 